\title{
Description of Aquimarina muelleri gen. nov., sp. nov., and proposal of the reclassification of [Cytophaga] latercula Lewin 1969 as Stanierella latercula gen. nov., comb. nov.
}

\author{
Olga I. Nedashkovskaya, ${ }^{1}$ Seung Bum Kim, ${ }^{2} \uparrow$ Anatoly M. Lysenko, ${ }^{3}$ \\ Galina M. Frolova, ${ }^{1}$ Valery V. Mikhailov, ${ }^{1}$ Kang Hyun Lee ${ }^{2}$ \\ and Kyung Sook Bae ${ }^{2}$
}

Correspondence

Olga I. Nedashkovskaya

olganedashkovska@yahoo.com

\begin{abstract}
${ }^{1}$ Pacific Institute of Bioorganic Chemistry of the Far-Eastern Branch of the Russian Academy of Sciences, Pr. 100 Let Vladivostoku 159, 690022, Vladivostok, Russia

${ }^{2}$ Korean Collection for Type Cultures, Biological Resources Center, Korea Institute of Bioscience and Biotechnology, Yusong, Daejon 305-333, Republic of Korea

${ }^{3}$ Institute of Microbiology of the Russian Academy of Sciences, Pr. 60 Let October 7/2, Moscow, 117811, Russia
\end{abstract}

The genus Cytophaga was proposed by Winogradsky (1929) to accommodate Gram-negative, motile by gliding, aerobic, pigmented and cellulolytic bacteria. Many other novel bacteria were later included in the genus Cytophaga, which was consequently emended by Reichenbach (1989) and Nakagawa \& Yamasato (1996). The latter authors proposed to restrict the polyphyletic genus Cytophaga to the species Cytophaga aurantiaca and Cytophaga hutchinsonii according to phylogenetic analysis data based on 16S rRNA gene sequence analysis. Novel genera were proposed for some Cytophaga species. For example, [Cytophaga] agarovorans

Published online ahead of print on 6 August 2004 as DOI 10.1099/ ijs.0.63349-0.

tPresent address: Department of Microbiology, School of Bioscience and Biotechnology, Chungnam National University, Yusong, Daejon 305-764, Republic of Korea.

The GenBank/EMBL/DDBJ accession numbers for the 16S rRNA gene sequences of Aquimarina muelleri KMM 6020 ${ }^{\top}, \mathrm{KMM} 6021$ and KMM 6028 are AY608406, AY608407 and AY608408, respectively.
Reichenbach 1989 and [Cytophaga] salmonicolor Veldkamp 1961 were reclassified as Marinilabilia agarovorans and Marinilabilia salmonicolor, respectively, by Nakagawa \& Yamasato (1996). These species were subsequently merged into a single species M. salmonicolor on the basis of DNADNA hybridization experiments (Suzuki et al., 1999). The novel genera Flammeovirga and Persicobacter were created, based on determination of their precise phylogenetic positions and polyamine compositions by Nakagawa et al. (1997), to accommodate [Cytophaga] aprica Reichenbach 1989 and [Cytophaga] diffluens Reichenbach 1989, respectively. Several Cytophaga species, [Cytophaga] aquatilis Strohl and Tait 1978, [Cytophaga] columnaris Bernardet and Grimont 1989, [Cytophaga] flevense van der Meulen et al. 1974, [Cytophaga] johnsoniae Stanier 1947, [Cytophaga] pectinivora Reichenbach 1989, [Cytophaga] psychrophila Reichenbach 1989, [Cytophaga] saccharophila Reichenbach 1989 and [Cytophaga] succinicans Reichenbach 1989, were transferred to the genus Flavobacterium (Bernardet et al., 1996). [Cytophaga] heparina Christensen 1980 was reclassified 
as Sphingobacterium heparinum Takeuchi and Yokota 1993 (effective publication by Takeuchi \& Yokota, 1992), and later transferred to the genus Pedobacter as Pedobacter heparinum (Steyn et al., 1998). The marine bacteria [Cytophaga] lytica Lewin 1969 and [Cytophaga] marina Reichenbach 1989 were included in the new genera Cellulophaga (Johansen et al., 1999) and Tenacibaculum (Suzuki et al., 2001), respectively, as the type species of these taxa. A marine bacterium isolated from a mud sample and described as [Flavobacterium] uliginosum (ZoBell \& Upham, 1944) is now included in the genus Zobellia (Barbeyron et al., 2001). Currently, only two of the 20 species initially included in the genus Cytophaga by Reichenbach (1989), [Cytophaga] latercula and [Cytophaga] marinoflava, together with [Cytophaga] fermentans Bachmann 1955, [Cytophaga] arvensicola Oyaizu et al. 1983 (effective publication by Oyaizu et al., 1982) and [Cytophaga] xylanolytica Haak and Breznak 1993, are considered as misnamed Cytophaga species and remain to be reclassified.

In the course of a study of a sea-water microbial population, novel heterotrophic, aerobic, Gram-negative, gliding and flexirubin-producing bacteria were isolated. 16S rRNA gene sequence analysis indicated that the isolates were members of the family Flavobacteriaceae, in which they form a distinct lineage. The closest relative of the strains studied was [Cytophaga] latercula (95.4\% sequence similarity). However, based on differences in the molecular and phenotypic features described here, we proposed that the KMM strains clearly differ from strain [Cytophaga] latercula CIP $104806^{\mathrm{T}}$ and represent a separate genus of the family Flavobacteriaceae. Consequently, we propose the description of the novel genus and species Aquimarina muelleri gen. nov., sp. nov., with type strain $\mathrm{KMM} 6020^{\mathrm{T}}$, and the reclassification of [Cytophaga] latercula Lewin 1969 in the new genus Stanierella as Stanierella latercula gen. nov., comb. nov., with type strain CIP $104806^{\mathrm{T}}$.

Strains KMM $6020^{\mathrm{T}}$, KMM 6021 and KMM 6028 were isolated from a sea-water sample collected in Amursky Bay, Gulf of Peter the Great, Sea of Japan. After primary isolation and purification on marine agar, strains were cultivated at $28^{\circ} \mathrm{C}$ on the same medium and stored at $-80{ }^{\circ} \mathrm{C}$ in marine broth supplemented with $20 \%(\mathrm{v} / \mathrm{v})$ glycerol.

Genomic DNA extraction, PCR and sequencing of the 16S rRNA gene followed the procedures of Kim et al. (1998). The sequence data obtained were aligned together with those of representative members of the family Flavobacteriaceae by PHYDIT version 3.2 (http://plaza.snu.ac.kr/ jchun/phydit/). Phylogenetic trees were inferred using suitable programs of the PHYLIP package (Felsenstein, 1993). Phylogenetic distances were calculated from the models of Kimura (1980), and phylogenetic trees were constructed on the basis of the neighbour-joining (Saitou \& Nei, 1987) and maximumlikelihood (Felsenstein, 1993) algorithms. Bootstrap analysis was performed with 1000 resamplings, using the SEQBOOT and CONSENSE programs of the PHYLIP package.

Phylogenetic 16S rRNA gene sequence analysis indicated that strains KMM $6020^{\mathrm{T}}$, KMM 6021 and KMM 6028 are members of the family Flavobacteriaceae and form a cluster with species of the genera Psychroflexus, Salegentibacter and Mesonia (Fig. 1). The closest relative of these strains is [Cytophaga] latercula CIP $104806^{\mathrm{T}}$, with $95 \cdot 4 \%$ sequence similarity.

DNA was isolated following the method of Marmur (1961) and $\mathrm{G}+\mathrm{C}$ content was determined by the thermal denaturation method of Marmur \& Doty (1962). The G $+C$ content of the DNA of the strains studied ranges from 31.6 to $32.5 \mathrm{~mol} \%$. DNA-DNA hybridizations were performed spectrophotometrically and initial renaturation rates were recorded as described by De Ley et al. (1970). The level of DNA-DNA relatedness between the KMM strains was $85-99 \%$. These values are significantly more than $70 \%$, and therefore suggest that the strains belong to the same species (Wayne et al., 1987).

Analysis of fatty acid methyl esters was carried out according to the standard protocol of the Microbial Identification System (Microbial ID). The major cellular fatty acids of the sea-water isolates were i15: $1, \mathrm{i} 15: 0, \mathrm{i} 15: 03-\mathrm{OH}, \mathrm{i} 17: 1 \omega 9 c$ and i17: $03-\mathrm{OH}(9 \cdot 8-13,19 \cdot 3-21 \cdot 1,5 \cdot 5-7 \cdot 5,9 \cdot 3-10 \cdot 6$ and $21-29 \cdot 5 \%$, respectively), and summed feature $3(7-8 \cdot 4 \%)$, comprising 16: $1 \omega 7$ and/or i15:0 2-OH fatty acids. Isoprenoid quinones were extracted from lyophilized cells and analysed as described by Nedashkovskaya et al. (2003c); the major respiratory quinone was MK-6.

Phenotypic analysis was performed using the methods of Nedashkovskaya et al. (2003a, b). Gliding motility was determined as described by Bowman (2000).

Physiological, biochemical and morphological characteristics of the strains studied are listed under the species

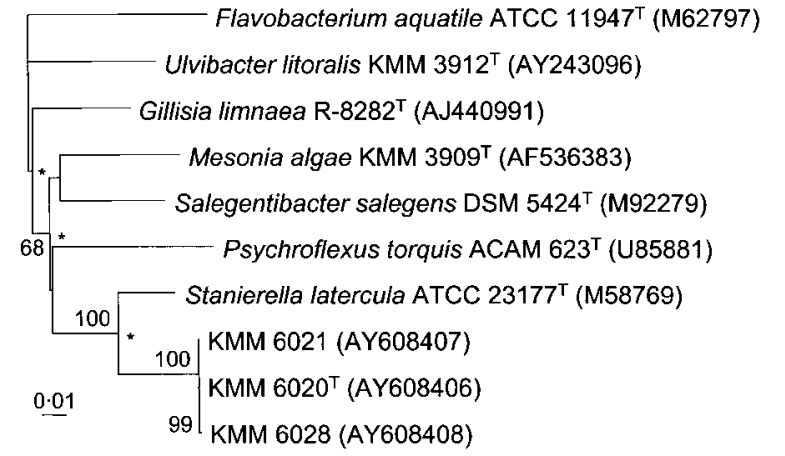

Fig. 1. Phylogenetic tree based on $16 \mathrm{~S}$ rRNA gene sequences of strains KMM 6020', KMM 6021 and KMM 6028 and representative members of related genera in the family Flavobacteriaceae. The tree was generated using the neighbourjoining method (Saitou \& Nei, 1987). Numbers at nodes indicate bootstrap values (\%), and asterisks indicate branches that were also recovered in the maximum-likelihood tree. Bar, 0.01 substitutions per nucleotide position. 
Table 1. Differential characteristics of the new genera Aquimarina and Stanierella and other allied genera of the family Flavobacteriaceae

Taxa: 1, Aquimarina muelleri gen. nov., sp. nov.; 2, Stanierella latercula gen. nov., comb. nov.; 3, Psychroflexus; 4, Salegentibacter; 5, Mesonia. Data from Reichenbach (1989), Dobson et al. (1993), Bowman et al. (1998), Nedashkovskaya et al. (2003c, 2004), Donachie et al. (2004) and this study. -, Negative; +, positive; $\mathrm{V}$, variable; ND, not detected.

\begin{tabular}{|lccccc|}
\hline Characteristic & $\mathbf{1}$ & $\mathbf{2}$ & $\mathbf{3}$ & $\mathbf{4}$ & $\mathbf{5}$ \\
\hline Gliding motility & + & - & $\mathrm{V}$ & - & - \\
Catalase & + & - & + & + & + \\
Flexirubins & + & - & - & - & - \\
Acid from carbohydrates & - & - & + & + & - \\
Growth at $15 \% \mathrm{NaCl}$ & - & - & $\mathrm{V}$ & $\mathrm{V}$ & + \\
Hydrolysis of: & & & & & \\
$\quad$ Agar & - & + & - & - & - \\
Casein & + & + & - & - & + \\
$\quad$ Starch & + & - & + & + & - \\
$\quad$ Alginate & - & + & $\mathrm{ND}$ & + & - \\
Chitin & + & + & - & - & - \\
$\quad$ DNA & + & + & + & + & - \\
Nitrate reduction & - & - & $\mathrm{V}$ & $\mathrm{V}$ & - \\
$\mathrm{H}_{2} \mathrm{~S}$ production & - & + & - & + & + \\
DNA G+C content $(\mathrm{mol} \%)$ & $31-33$ & 34 & $32-36$ & $37-38$ & $32-34$ \\
& & & & &
\end{tabular}

description and are also given in Table 1. Phenotypic examination demonstrated many common traits between the strains studied and [Cytophaga] latercula. However, the KMM strains differ sufficiently from their closest relative on the basis of the ability to move by gliding motility, catalase activity, hydrolysis of agar and starch, flexirubin pigments and hydrogen sulphide production. Differential characteristics of the strains studied and their nearest relatives are shown in Table 1.

Based on the phenotypic, chemotaxonomic and molecular characteristics described here, we propose the creation of a novel genus and species Aquimarina muelleri gen. nov., sp. nov. for strains KMM 6020 ${ }^{\mathrm{T}}$, KMM 6021 and KMM 6028. In addition, we propose the reclassification of [Cytophaga] latercula CIP $104106^{\mathrm{T}}$ to the genus Stanierella as Stanierella latercula gen. nov., comb. nov.

\section{Description of Aquimarina gen. nov.}

Aquimarina (A.qui.ma.ri'na. L. fem. n. aqua water; L. adj. marinus, $-a$, -um marine; N.L. adj. aquimarina living in sea water).

Rod-shaped cells, motile by gliding. Gram-negative. Do not form endospores. Strictly aerobic. Produce non-diffusible yellow pigments. Chemo-organotroph. Cytochrome oxidase-, catalase- and alkaline phosphatase-positive. The predominant cellular fatty acids are straight-chain saturated, branched-chain saturated and unsaturated fatty acids:

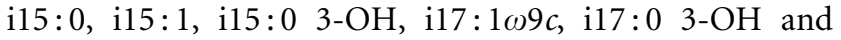
summed feature 3 (comprising $16: 1 \omega 7 c$ and/or i15: $02-\mathrm{OH}$ fatty acids). The main lipoquinone is MK-6. 16S rRNA gene sequence analysis indicates the genus Aquimarina is a member of the family Flavobacteriaceae, phylum 'Bacteroidetes'. The type species is Aquimarina muelleri.

\section{Description of Aquimarina muelleri sp. nov.}

Aquimarina muelleri [muel'le.ri. N.L. gen. n. muelleri of Müller, in honour of Otto Friedrich Müller (1730-1784), the famous Danish naturalist, for his contributions to the development of marine microbiology].

Characteristics are as given for the genus. In addition, cells are $0 \cdot 3-0 \cdot 5 \mu \mathrm{m}$ in width and $5-7 \mu \mathrm{m}$ in length. Colonies are irregularly shaped, flat, with non-entire edges and 3-5 mm in diameter on marine agar 2216. Produces dark yellow to brown non-diffusible pigments. No growth is observed without $\mathrm{Na}^{+}$. Growth occurs at $1-8 \% \mathrm{NaCl}$. Flexirubin pigments are formed. Growth occurs at $4-34^{\circ} \mathrm{C}$. Casein, gelatin, starch, DNA and Tweens 20, 40, 60 and 80 are degraded. Does not hydrolyse agar, alginate, urea, chitin or cellulose (CM-cellulose or filter paper). Does not form acid from arabinose, cellobiose, fucose, galactose, glucose, lactose, maltose, melibiose, raffinose, rhamnose, sucrose, xylose, adonitol, dulcitol, glycerol, inositol, mannitol or $\mathrm{N}$-acetylglucosamine. Does not utilize arabinose, glucose, lactose, mannose, sucrose, inositol, mannitol, sorbitol, citrate or malonate as sole sources of carbon and energy. Nitrate reduction is negative. $\mathrm{H}_{2} \mathrm{~S}$, indole and acetoin (Voges-Proskauer reaction) are not produced. Susceptible to ampicillin, carbenicillin, lincomycin and oleandomycin. Resistant to benzylpenicillin, gentamicin, kanamycin, neomycin and polymyxin B. The predominant cellular fatty acids are straight-chain unsaturated, branched-chain unsaturated and saturated: i15:0 (19.3-21.1\%), i15:1 $(9 \cdot 8-13 \%)$, i15:0 $3-\mathrm{OH}(5 \cdot 5-7 \cdot 5 \%)$, i17: $1 \omega 9 \mathrm{c}(9 \cdot 3-$ $10 \cdot 6 \%)$, i17:0 $3-\mathrm{OH}(21-29 \cdot 5 \%)$ and summed feature 3 (7-8.4\%; comprising i15:0 $2-\mathrm{OH}$ and/or $16: 1 \omega 7 c$ fatty acids). $\mathrm{G}+\mathrm{C}$ content of the DNA is $31 \cdot 6-32 \cdot 5 \mathrm{~mol} \%$.

The type strain, KMM $6020^{\mathrm{T}}\left(=\mathrm{KCTC} 12285^{\mathrm{T}}=\mathrm{LMG}\right.$ $22569^{\mathrm{T}}$ ), was isolated from a sea-water sample collected in Amursky Bay, Gulf of Peter the Great, Sea of Japan.

\section{Description of Stanierella gen. nov.}

Stanierella [Sta'ni.er.el.la. L. dim. ending -ella; N.L. fem. n. Stanierella named in honour of the famous Canadian microbiologist Roger Y. Stanier (1916-1982), for his important contributions to the development of marine microbiology and the taxonomy of the Cytophaga-like bacteria].

Rod-shaped cells, non-motile. Gram-negative. Do not form endospores. Strictly aerobic. Produces non-diffusible pigments. No flexirubins are formed. Chemo-organotroph. Cytochrome oxidase- and alkaline phosphatase-positive; catalase-negative. The main lipoquinone is MK-6. 16S rRNA gene sequence analysis indicates the genus Stanierella is a 
member of the family Flavobacteriaceae, phylum 'Bacteroidetes'. The type species is Stanierella latercula.

\section{Description of Stanierella latercula comb. nov.}

Stanierella latercula (la.ter'cu.la. L. masc. n. laterculus a small brick; N.L. fem. adj. latercula brick-like, brick-red colour).

\section{Basonym: Cytophaga latercula Lewin 1969.}

The description is as given for the genus and by Reichenbach (1989), with the addition that it is $\beta$-galactosidase-positive. Degrades casein, DNA and Tweens 20, 40 and 80, but not urea or cellulose (CM-cellulose or filter paper). Does not form acid from L-arabinose, D-cellobiose, L-fucose, D-galactose, D-glucose, D-lactose, D-maltose, D-melibiose, L-raffinose, L-rhamnose, D-sucrose, DL-xylose, adonitol, dulcitol, glycerol, inositol, mannitol or $\mathrm{N}$-acetylglucosamine. Growth occurs at $4-34^{\circ} \mathrm{C}$ and at $1-5 \% \mathrm{NaCl}$. Susceptible to ampicillin, lincomycin, oleandomycin and streptomycin. Resistant to benzylpenicillin, carbenicillin, gentamicin, kanamycin, neomycin and polymyxin B. The predominant cellular fatty acids are straight-chain saturated, branched-chain saturated and unsaturated fatty acids: i15:0 $(18 \cdot 2 \%), \mathrm{i} 15: 1 \mathrm{w} 10 c(6 \cdot 7 \%), 15: 0(5 \cdot 4 \%)$, i15: $03-\mathrm{OH}$ $(7 \cdot 1 \%)$, i17: $1 \omega 7 c(11 \cdot 6 \%)$ and i17:0 $3-\mathrm{OH}(34 \cdot 7 \%)$ (Bowman et al., 1998). G+C content of the DNA is $34 \mathrm{~mol} \%$.

The type strain, CIP $104806^{\mathrm{T}}\left(=\mathrm{ATCC} 23177^{\mathrm{T}}=\mathrm{NCIMB}\right.$ $1399^{\mathrm{T}}=\mathrm{LMG} 1343^{\mathrm{T}}$ ), was isolated from the outflow of a marine aquarium in La Jolla, CA, USA.

\section{Acknowledgements}

This research was supported by grants of the Federal Agency for Sciences and Innovations of the Ministry for Education and Sciences of the Russian Federation no. 2-2.16, Russian Foundation for Basic Research no. 05-04-48211 and Program of Fundamental Investigations of the Presidium of the Russian Academy of Sciences 'Molecular and Cell Biology'. S. B. K. and K. S. B. acknowledge support from the KRIBB Research Initiative Program.

\section{References}

Bachmann, B. J. (1955). Studies on Cytophaga fermentans n. sp., a facultatively anaerobic lower myxobacterium. J Gen Microbiol 13, 541-551.

Barbeyron, T., L'Haridon, S., Corre, E., Kloareg, B. \& Potin, P. (2001). Zobellia galactanovorans gen. nov., sp. nov., a marine species of Flavobacteriaceae isolated from red alga, and classification of [Cytophaga] uliginosa (ZoBell and Upham 1944) Reichenbach 1989 as Zobellia uliginosa gen. nov., comb. nov. Int J Syst Evol Microbiol 51, 985-997.

Bernardet, J.-F. \& Grimont, P. A. D. (1989). Deoxyribonucleic acid relatedness and phenotypic characterization of Flexibacter columnaris sp. nov., nom. rev., Flexibacter psychrophilus sp. nov., nom. rev., and Flexibacter maritimus Wakabayashi, Hikida, and Masumura 1986. Int J Syst Bacteriol 39, 346-354.
Bernardet, J.-F., Segers, P., Vancanneyt, M., Berthe, F., Kersters, K. \& Vandamme, P. (1996). Cutting a Gordian knot: emended classification and description of the genus Flavobacterium, emended description of the family Flavobacteriaceae, and proposal of Flavobacterium hydatis nom. nov. (basonym Cytophaga aquatilis Strohl and Tait 1978). Int J Syst Bacteriol 46, 128-148.

Bowman, J. P. (2000). Description of Cellulophaga algicola sp. nov., isolated from the surfaces of Antarctic algae, and reclassification of Cytophaga uliginosa (ZoBell and Upham 1944) Reichenbach 1989 as Cellulophaga uliginosa comb. nov. Int J Syst Evol Microbiol 50, 1861-1868.

Bowman, J. P., McCammon, S. A., Lewis, T., Skerratt, J. H., Brown, J. L., Nichols, D. S. \& McMeekin, T. A. (1998). Psychroflexus torquis gen. nov., sp. nov., a psychrophilic species from Antarctic sea ice, and reclassification of Flavobacterium gondwanense (Dobson et al. 1993) as Psychroflexus gondwanense sp. nov., comb. nov. Microbiology 144, 1601-1609.

Christensen, P. (1980). Description and taxonomic status of Cytophaga heparina (Payza and Korn) comb. nov. (basonym: Flavobacterium heparinum Payza and Korn 1956). Int J Syst Bacteriol 30, 473-475.

De Ley, J., Cattoir, H. \& Reynaerts, A. (1970). The quantitative measurement of DNA hybridization from renaturation rates. Eur J Biochem 12, 133-142.

Dobson, S. J., Colwell, R. R., McMeekin, T. A. \& Franzmann, P. D. (1993). Direct sequencing of the polymerase chain reaction-amplified $16 \mathrm{~S}$ rRNA gene of Flavobacterium gondwanense sp. nov. and Flavobacterium salegens sp. nov., two new species from a hypersaline Antarctic lake. Int J Syst Bacteriol 43, 77-83.

Donachie, S. P., Bowman, J. P. \& Alam, M. (2004). Psychroflexus tropicus sp. nov., an obligately halophilic Cytophaga-FlavobacteriumBacteroides group bacterium from an Hawaiian hypersaline lake. Int J Syst Evol Microbiol 54, 935-940.

Felsenstein, J. (1993). PHYLIP (Phylogeny Inference Package), version 3.5c. Distributed by the author. Department of Genetics, University of Washington, Seattle, USA.

Haak, S. K. \& Breznak, J. A. (1993). Cytophaga xylanolytica sp. nov., a xylan-degrading, anaerobic gliding bacterium. Arch Microbiol 159, 6-15.

Johansen, J. E., Nielsen, P. \& Sjøholm, C. (1999). Description of Cellulophaga baltica gen. nov., sp. nov. and Cellulophaga fucicola gen. nov., sp. nov. and reclassification of [Cytophaga] lytica to Cellulophaga lytica gen. nov., comb. nov. Int J Syst Bacteriol 49, 1231-1240.

Kim, S. B., Falconer, C., Williams, E. \& Goodfellow, M. (1998). Streptomyces thermocarboxydovorans sp. nov. and Streptomyces thermocarboxydus sp. nov., two moderately thermophilic carboxydotrophic species isolated from soil. Int J Syst Bacteriol 48, 59-68.

Kimura, M. (1980). A simple method for estimating evolutionary rates of base substitutions through comparative studies of nucleotide sequences. J Mol Evol 16, 111-120.

Lewin, R. A. (1969). A classification of flexibacteria. J Gen Microbiol 58, 189-206.

Marmur, J. (1961). A procedure for the isolation of deoxyribonucleic acid from microorganisms. J Mol Biol 3, 208-218.

Marmur, J. \& Doty, P. (1962). Determination of the base composition of deoxyribonucleic acid from its thermal denaturation temperature. J Mol Biol 5, 109-118.

Nakagawa, Y. \& Yamasato, K. (1996). Emendation of the genus Cytophaga and transfer of Cytophaga salmonicolor to Marinilabilia gen. nov.: phylogenetic analysis of the Flavobacterium-Cytophaga complex. Int J Syst Bacteriol 46, 599-603. 
Nakagawa, Y., Hamana, K., Sakane, T. \& Yamasato, K. (1997). Reclassification of Cytophaga aprica (Lewin 1969) Reichenbach 1989 in Flammeovirga gen. nov. as Flammeovirga aprica comb. nov. and Cytophaga diffluens (ex Stanier 1940; emend. Lewin 1969) Reichenbach 1989 in Persicobacter diffluens comb. nov. Int J Syst Bacteriol 47, 220-223.

Nedashkovskaya, O. I., Suzuki, M., Vysotskii, M. V. \& Mikhailov, V. V. (2003a). Reichenbachia agariperforans gen. nov., sp. nov., a novel marine bacterium in the phylum Cytophaga-FlavobacteriumBacteroides. Int J Syst Evol Microbiol 53, 81-85.

Nedashkovskaya, O. I., Suzuki, M., Vysotskii, M. V. \& Mikhailov, V. V. (2003b). Vitellibacter vladivostokensis gen. nov., sp. nov., a new member of the phylum Cytophaga-Flavobacterium-Bacteroides. Int J Syst Evol Microbiol 53, 1281-1286.

Nedashkovskaya, O. I., Kim, S. B., Han, S. K. \& 7 other authors (2003c). Mesonia algae gen. nov., sp. nov., a novel marine bacterium of the family Flavobacteriaceae isolated from the green alga Acrosiphonia sonderi (Kütz) Kornm. Int J Syst Evol Microbiol 53, 1967-1971.

Nedashkovskaya, O. I., Suzuki, M., Vancanneyt, M., Cleenwerck, I., Zhukova, N. V., Vysotskii, M. V., Mikhailov, V. V. \& Swings, J. (2004). Salegentibacter holothuriorum sp. nov., isolated from edible holothurian Apostichopus japonicus. Int J Syst Evol Microbiol 54, 1107-1110.

Oyaizu, H., Komagata, K., Amemura, A. \& Harada, T. (1982). A succinoglycan-decomposing bacterium, Cytophaga arvensicola $\mathrm{sp}$. nov. J Gen Appl Microbiol 28, 369-388.

Oyaizu, H., Komagata, K., Amemura, A. \& Harada, T. (1983). Cytophaga arvensicola sp. nov. In Validation of the Publication of New Names and New Combinations Previously Effectively Published Outside the IJSB, List no. 10. Int J Syst Bacteriol 33, 438-440.

Reichenbach, H. (1989). Order Cytophagales Leadbetter 1974, $99^{\mathrm{AL}}$ In Bergey's Manual of Systematic Bacteriology, vol. 3, pp. 2011-2073. Edited by J. T. Staley, M. P. Bryant, N. Pfennig \& J. C. Holt. Baltimore: Williams \& Wilkins.

Saitou, N. \& Nei, M. (1987). The neighbor-joining method: a new method for reconstructing phylogenetic trees. Mol Biol Evol 4, 406-425.

Stanier, R. Y. (1947). Studies on nonfruiting myxobacteria. I. Cytophaga johnsonae, n. sp., a chitin-decomposing myxobacterium. J Bacteriol 53, 297-315.

Steyn, P. L., Segers, P., Vancanneyt, M., Sandra, P., Kersters, K. \& Joubert, J. J. (1998). Classification of heparinolytic bacteria into a new genus, Pedobacter, comprising four species: Pedobacter heparinus comb. nov., Pedobacter piscium comb. nov., Pedobacter africanus sp. nov. and Pedobacter saltans sp. nov. Proposal of the family Sphingobacteriaceae fam. nov. Int J Syst Bacteriol 48, 165-177.

Strohl, W. R. \& Tait, L. R. (1978). Cytophaga aquatilis sp. nov., a facultative anaerobe isolated from the gills of freshwater fish. Int J Syst Bacteriol 28, 293-303.

Suzuki, M., Nakagawa, Y., Harayama, S. \& Yamamoto, S. (1999). Phylogenetic analysis of genus Marinilabilia and related bacteria based on the amino acid sequences of GyrB and emended description of Marinilabilia salmonicolor with Marinilabilia agarovorans as its subjective synonym. Int J Syst Bacteriol 49, 1551-1557.

Suzuki, M., Nakagawa, Y., Harayama, S. \& Yamamoto, S. (2001). Phylogenetic analysis and taxonomic study of marine Cytophaga-like bacteria: proposal for Tenacibaculum gen. nov. with Tenacibaculum maritimum comb. nov., and Tenacibaculum ovolyticum comb. nov., and description of Tenacibaculum mesophilum sp. nov. and Tenacibaculum amylolyticum sp. nov. Int J Syst Evol Microbiol 51, 1639-1652.

Takeuchi, M. \& Yokota, A. (1992). Proposals of Sphingobacterium faecium sp. nov., Sphingobacterium piscium sp. nov., Sphingobacterium heparinum comb. nov., Sphingobacterium thalpophilum comb. nov., and two genospecies of the genus Sphingobacterium and synonymy of Flavobacterium yabuuchiae and Sphingobacterium spiritivorum. J Gen Appl Microbiol 38, 465-482.

Takeuchi, M. \& Yokota, A. (1993). Sphingobacterium heparinum comb. nov. In Validation of the Publication of New Names and New Combinations Previously Effectively Published Outside the IJSB, List no. 47. Int J Syst Bacteriol 43, 864-865.

Van der Meulen, H. J., Harder, W. \& Veldkamp, H. (1974). Isolation and characterization of Cytophaga flevensis sp. nov., a new agarolytic flexibacterium. Antonie van Leeuwenhoek 40, 329-346.

Veldkamp, H. (1961). A study of two marine agar-decomposing, facultatively anaerobic myxobacteria. J Gen Microbiol 26, 331-342.

Wayne, L. G., Brenner, D. J., Colwell, R. R. \& 9 other authors (1987). Report of the ad hoc committee on reconciliation of approaches to bacterial systematics. Int J Syst Bacteriol 37, 463-464.

Winogradsky, S. (1929). Études sur la microbiologie du sol - sur la dégradation de la cellulose dans le sol. Ann Inst Pasteur 43, 549-633 (in French).

ZoBell, C. E. \& Upham, H. C. (1944). A list of marine bacteria including descriptions of sixty new species. Bull Scripps Inst Oceanogr Univ Calif 5, 239-292. 